\title{
VAK Learning Style Identification of PGSD UKI Toraja Students
}

\author{
Mersilina L. Patintingan ${ }^{1}$, Reni Lolotandung ${ }^{2}$, Theresyam Kabanga ${ }^{3}$ \\ \{mersilina@ukitoraja.ac.id ${ }^{1}$, renilolotandung@ukitoraja.ac.id² ${ }^{2}$ theresyam@ukitoraja.ac.id ${ }^{3}$ \} \\ 1,2,3 Universitas Kristen Indonesia Toraja, J1. Nusantara No.12 Makale 91811, Tana Toraja, Indonesia
}

\begin{abstract}
Learning style refers to the way students learn. This research was conducted with the aim to increase learning outcomes of the weak student by diagnosis (knowing their weaknesses in learning, and providing solutions about appropriate learning methods), which is expected to reveal the factors that influence students in learning by citing learning designs of Rita and Kenneth Dunn. After completing the Learning Style Questionnaire, an analysis/calculation of the results for each research topic was carried out. In this study, 6 groups of learning style tendencies are identified to draw conclusions for a learning style. The results of the diagnosis can later be used as a reference in designing appropriate methods to improve learning outcomes.
\end{abstract}

Keywords: Visual learning style, auditory learning styles, kinestetic learning styles; students.

\section{Introduction}

One of the factors affecting the outcome of one's learning is the learning style [1]. Dividing student classes based on each individual's learning style will greatly assist the lecturers in preparing the appropriate teaching methods and materials to the student's learning style.

The VAK (Visual, Auditory, and Kinesthetic) learning style was developed by Rita Dunn and Kenneth Dunn. People with the visual learning styles tend to learn through external visual relations, people with the auditory learning styles will be easier to learn by listening, while those who learn with the kinesthetic learning styles learn through physical movements as a means of entering information into their brains [2].

However, the lecturer's attention to student learning style is still relatively low, which has an impact on the inaccuracy of the methods applied in order to maximize learning outcomes. Knowing a person's learning style will help them to absorb information maximally. Learning style refers to the way students learn. This research was conducted with the aim to increase learning outcomes of the weak student by diagnosis (knowing their weaknesses in learning, and providing solutions about appropriate learning methods), which is expected to reveal the factors that influence students in learning by citing learning designs of Rita and Kenneth Dunn. The results of the diagnosis can later be used as a reference in designing appropriate methods to improve learning outcomes.

Learning style is the easiest way for individuals to absorb, organize, and process the information they receive [3]. A suitable learning style is the key to someone's success in learning [4]. Therefore in learning activities, students need to be assisted and directed to 
recognize the appropriate learning style to them so that the learning objectives can be achieved effectively.

According to Rita Dunn in Ria Putri, there are 3 (three) types of people in learning: Visual, Auditory, Kinaesthetic (VAK). The visual learner learns through what they see, the auditory learner learns by hearing and the kinaesthetic learner learns by moving, working and touching. Each person has all these three learning styles, but one type dominates others. Learning styles also affect learning outcomes [5]. Learning outcomes are the final state, it is also a competence and change that a person has through repetitive process and recognition, it will be stored for a long time because learning outcomes participate in forming a person who always wants to achieve better results, then leads to the change in the way of thinking and results in better work behavior.

\section{Method}

This research is a descriptive study with the qualitative approach"Metode penelitian kualitatif adalah metode penelitian yang berlandaskan pada filsafat postpositivisme, digunakan untuk meneliti pada kondisi obyek yang alamiah, (sebagai lawannya adalah eksperimen) dimana peneliti adalah sebagai instrumen kunci, pengambilan sampel sumber data dilakukan secara purposive dan snowbal, teknik pengumpulan dengan trianggulasi (gabungan), analisis data bersifat induktif kualitatif, dan hasil penelitian lebih menekankan makna dari pada generalisasi. " [6] which means, the qualitative research method is a research method based on the philosophy of Postpositivism, is used to examine the condition of the object that is natural, (as its opponent is the experiment) in which researcher is a key instrument, using a sampling source by purposive and snowball, using the triangulation data collection technique (combined), qualitative data analysis is inductive, and the result of research emphasize more on the meaning rather than the generalization. 


\subsection{Research Population}

Research Population. The subject of this study were all students of PGSD UKI Toraja who passed the selection test on new admission of UKI Toraja for academic year 2018/2019 totalling 250 students.

\subsection{Data Collection Instruments}

Data Collection Instruments. 1. Closed questionnaire using the SelfMap Application. The instrument used in this study was a questionnaire answered by the research subjects. The questionnaire contains a number of questions used to obtain information from research subjects related to their learning styles. The questionnaire instrument was not tested but only validated by linguists to avoid ambiguity or multiple interpretations of questions.

Judging from the way to answer the questions, the questionnaire used was a closed questionnaire because the answer choices was provided. based on the answer, the questionnaire used was a direct questionnaire because the research subjects answered directly about themselves. Questionnaire data obtained from each respondent was recapitulated based on each learning style. The following are some steps in analyzing the data.

A number of questions were provided on the questionnaire instrument to be answered by respondents. There were 3 groups of questions reflecting each learning style: The "V"(Visual), the "A" (Auditory), the "K" (Kinesthetic). Each question had answer-choice as follows: "Often" was given a score of 2, "sometimes" was given a score of 1 , and "rarely" was given a score of 0 .

Scores from each group of learning style questions were accumulated to produce a certain value. The conclusion drawn from the learning styles tendencies was by comparing the three values of each group of questions answered by the subjects. Conclusions are based on:

a). If the highest score arises from a group of learning style questions, it is concluded that the subject tends to be dominant in that learning style;

b).If two highest scores appear from two groups of learning style questions, then the subject belongs to the "Combination of both Learning Styles".

c). If two highest scores appear from two groups of learning style questions that have a difference of 1 point, then the subject belongs to the "Combination of the two Learning Styles".

d). After that, a recapitulation will be made in the form of: Percentage of learning style tendencies of each student, and Percentage of learning style tendencies of overall of students.

\section{Results and discussion}

Results and discussion. After completing the Learning Style Questionnaire, an analysis/calculation of the results for each research topic was carried out. In this study, 6 groups of learning style tendencies are identified to draw conclusions for a learning style:

\section{1). Visual Learning Style (symbolized 'V')}

Based on the results of the student questionnaires, an overview is drawn up to show that students who tend to learn with visual style are identified as follows: Speak quickly often, remember easily when they are visually associated (Remember the things seen more easily than heard and done), not disturbed by the excitement of learning, can see the actual words in his head, faster reader, only weakness is difficult to remember, verbal instructions, sometimes concentration to lose and forget to convey verbal messages to others. 


\section{2) Auditory Learning Style (symbolized 'A')}

In analyzing the results of the student questionnaires, it was outlined that students whose tendency to learn in a visual style would look like this: If they enjoy learning in a quiet, quiet and alert private setting, it is difficult to concentrate when they are in a noisy environment and speak fluently With explanations, they can repeat and imitate the tone, beat, and tone of the voice by listening and remembering what is being discussed instead of being seen, talking, discussing and explain in some detail, have problems related to occupations Visualizations, such as the cutting of parts, are easier to express verbally than in writing

\section{3) Kinesthetic Learning Style (symbolized ' $K$ ')}

Pupils who have a tendency toward this kinesthetic learning style will speak slowly, respond easily to physical attention, touch other people to attract their attention, stand up and listen when talking to people, orientate themselves to physical activity, and move Learn by manipulating and practicing to memorize by walking and seeing, using fingers as a pointer while reading, using fingers as a pointer while reading. Many use body cues and like books based on the plot - they reflect actions with body movements in reading that are generally written ugly and always want to do or try anything.

\section{4) Combining of Visual and Audiory learning styles (symbolized 'VA')}

Students who have a tendency to combine these two learning styles, they tend to be active in listening and writing, in the results of reading, taking into account nobody there is a direct underlines his or menstabilo and there are also students who menulanginya live out loud read

\section{5) Combining of Visual and Kinestetik learning styles (symbolized 'VK')}

Some students who tend to have this visual kinaesthetic learning style become nervous when they need to present something in front of the class. They will feel better when supported with media such as LCDs, slides, materials, and experimental tools to help them express their ideas and ideas

\section{6) Combining of Kinestetik and Auditori learning styles (symbolized 'KA')}

In addition to being satisfied with the teacher's explanation, students with this tendency have activities such as writing writings that are considered important and that usually follow body parts and body movements, such as playing with a writing utensil or one of their feet.

\section{Conclusions}

Conclusions. Based on the results of the research and discussion on identifying the learning style characteristics of UKI Toraja students in the Primary Teacher Training Program 2019, it can be concluded that the auditory learning style is most prevalent in this area, ie $40 \%$ or a total of 100 people with reference to the characteristics the easier learning in discussion and explanation and hard to learn in a noisy atmosphere, followed second is the tendency of visual learning styles that are $30 \%$ or up to 75 people with happy reading and comfortable learning in clean conditions only the verbal information is fast to forget . Third, kinaesthetic learning tendencies with a $15 \%$ percentage or a number of 37 people with learning characteristics in the form of exercises would be very simple and very happy in the form of joint projects. 



\section{References}

[1] Sawitri Dwi Pratiti.2009.Pengaruh Faktor Preferensi Gaya Belajar Terhadap Prestasi Belajar Mahasiswa Akuntansi.Jurnal Ekonomi Bisnis.ISSN 0853-7283

[2] Ria Putri Palupijati.2012. Model Pembelajaran Visual Audio Kinestetik dalam meningkatkan hasil belajar siswa di SDN Sleman Yogyakarta. Jurnal PGSD UNY

[3] Chatib, munif.2014.Orangtuanya Manusia: Melestarikan Potensi dan Kecerdasan dengan Menghargai Fitrah Setiap Anak. Bandung:PT Mizan Pustaka.

[4] Adlia Afriani, dkk.2017.Analisis Kebutuhan Belajar Mahasiswa pada Mata kuliah Strategi pembelajaran TI. Prosiding Seminar pendidikan IPA Pascasarjana UM. Vol. 2.2017, ISBN:978-602-9286-22-9.

[5] Endang Nugraheni, dkk.2003.Gaya belajar dan Strategi Belajar Mahasiswa Jarak Jauh: Kasus di Universitas Terbuka.Jakarta

[6] Dewi Iriani.2013.Identifikasi Gaya Belajar dan Pengaruhnya Terhadap Hasil Belajar Siswa pada Materi Kubus dan Balok di Kelas VIII SMPN 2 Kerinci.Prosiding Semirata FMIPA Universitas Lampung

[7] Jeanete O.P. \& Neleke H.(2016).Identifikasi Gaya Belajar Mahasiswa.Jurnal Psikologi Undip Vol 15 No. 1 April 2016, 56-63

[8] Yusri Wahyuni.(2017).Identifikasi Gaya Belajar (Visual, Auditorial,Kinestetik) Mahasiswa Pendidikan Matematika, Universitas Bung Hatta.Jurnal Penelitian dan Pembelajaran Matematika (Jurnal Untirta) Volume 10 no. 2 Agustus 2017

[9] Umy Zahroh dan Beni Asyar.(2014).Kecenderungan Gaya Belajar Mahasiswa dalam Menyelesaikan Masalah Fungsi Bijektif.Jurnal kebijakan dan Pengembangan Pendidikan Vol. 2 No. 1, Januari 2014, 72-81

[10] Triferga prasetyo \& Muhammad Iqbal.(2016).Sistem Pakar Identifikasi Gaya Belajar Mahasiswa Berbasis Web.Prosiding Seminar Nasional Sains \& Teknologi Fakultas Teknik Universitas Muhammadiyah Jakarta, 8 November 2016

[11] Ariesta Kartika Sari, dkk.2014. Analisis Karakteristik Gaya Belajar VAK (Visual Audio Kinestetik) Mahasiswa Pendidikan Informatika Angkatan 2014.Jurnal Ilmiah Educatic Vol. 1/ No. 1, Nopember 2014 ISSN 2407-4484. Bangkalan.

[12] Yeni P.P, Ngadiman \& Sohidin.(2017).Identifikasi Gaya Belajar Siswa Akuntasi SMK X Tahun Pelj. 2017/2018.Jurnal Pendidikan Akuntasi Tata Arta Vol. 3, No. 2

[13] Mulyati.Identifikasi Gaya Belajar Siswa Kelas V SD seGugus 3 Kecamatan Pengasih Kabupaten Kulonprogo T.A 2014.Jurnal FKIP UNS

[14] Gita Melinda, Asih Widi W.(2018).Identifikasi Gaya Belajar Model KOLB terhadap Peserta Didik MAN II Yogyakarta.Jurnal Pendidikan Sains (JPS) Vol. 06 No. 01 2018, 47-55

[15] A.L. Bire.(2014).Pengaruh Gaya Belajar Visual, Auditorial dan Kinestetik terhadap Prestasi Belajar Siswa.Jurnal Kependidikan UNY, Vol.44 No.2 November 2014 hal $168-174$ 